\title{
Functional genomics of the peripheral blood response to allergen inhalation challenge
}

\author{
Sarah HY Kam¹, Jian Ruan ${ }^{1}$, Gail M Gauvreau², Paul M O'Byrne², J Mark FitzGerald ${ }^{3}$, Scott J Tebbutt ${ }^{\text {* }}$ \\ From AllerGen NCE Inc.'s Fifth Annual Research Conference: Innovation from Cell to Society \\ Québec City, QC, Canada. 7-9 February 2010
}

\section{Objective/purpose}

In asthmatic individuals, airway narrowing represents the early phase of the asthmatic response to allergen inhalation challenge, occurring within thirty minutes [1]. In $50-60 \%$ of allergic asthmatic adults, the early response is followed by the late phase asthmatic response, usually starting between 3-4 hours after allergen inhalation challenge [2], and characterized mainly by cellular inflammation of the airway [3]. The pathways leading to the late response are not completely understood. Understanding these pathways is important for evaluating allergic diseases such as asthma. In contrast to the more transient isolated early response, development of the late response is associated with the hallmark inflammatory features of chronic allergic disease.

\section{Methods}

Nine adult subjects participating in ethically approved allergen challenge studies were recruited following informed consent. Inclusion criteria included non-smokers with stable, mild to moderate atopic asthma, free of other lung diseases. Subjects developing either an isolated early asthmatic response ( $\geq 20 \%$ drop in FEV1 within 2 hours) or the dual asthmatic response (early response $+\geq 15 \%$ drop in FEV1 between 3-7 hours) were studied. Peripheral blood was drawn just prior to inhalation challenge and 2-3 hours post-challenge. Gene expression analysis was performed using Affymetrix GeneChip microarrays.

\section{Findings}

1783 genes were differentially expressed between preand post-inhalation challenge $(\mathrm{p} \leq 0.01) .364$ genes

\footnotetext{
* Correspondence: scott.tebbutt@hli.ubc.ca

'UBC James Hogg Research Centre, St. Paul's Hospital, University of British

Columbia, Vancouver, BC, V6Z 1Y6, Canada

Full list of author information is available at the end of the article
}

remained significant at an FDR of $10 \%$. Within this set, the DNAJC1 gene $(\mathrm{p}=7.2 \mathrm{e}-5)$ has been previously identified in a GWAS (genome-wide association study) as associated with asthma. Gene ontology showed perturbed activity in immune system process, mast cell secretory granules and immunoglobulin biosynthesis.

\section{Deliverables}

The peripheral blood transcriptome was perturbed between pre-allergen inhalation challenge and 2-3 hours post-challenge, with a focus on immunological functions. DNAJC1 was identified to be a gene for possible further investigation. Additional recruitment of subjects is underway to identify more specific biological pathways that may be relevant to the onset of the late asthmatic response.

\section{Relevance}

This research will act as an initial step in identifying genes and pathways that may be involved in the more clinically severe late asthmatic response that follows the early response in more than half of the asthmatic population. The discovery of these biological pathways will allow for a better understanding of why some individuals develop a dual response instead of an isolated early response. It will also indicate potential therapeutic targets that can be utilized to minimize the late asthmatic response, leading to better treatments for people with asthma and other allergies.

\section{Acknowledgements}

We would like to thank the research participants for their involvement in this project. This research is made possible by financial support from AllerGen NCE.

\section{Author details}

'UBC James Hogg Research Centre, St. Paul's Hospital, University of British Columbia, Vancouver, BC, V6Z 1Y6, Canada. ²Department of Medicine, 
McMaster University, Hamilton, Ontario, L8N 3Z5, Canada. ${ }^{3}$ Centre for Lung Health, University of British Columbia, Vancouver, BC, V5Z 1M9, Canada.

Published: 26 November 2010

\section{References}

1. Gauvreau GM, Evans MY: Allergen inhalation challenge: a human model of asthma exacerbation. Contrib Microbiol 2007, 14:21-32.

2. Robertson DG, Kerigan AT, Hargreave FE, Chalmers R, Dolovich J: Late asthmatic responses induced by ragweed pollen allergen. J Allergy Clin Immunol 1974, 54(4):244-254.

3. Cieslewicz G, Tomkinson A, Adler A, Duez C, Schwarze J, Takeda K, Larson KA, Lee JJ, Irvin CG, Gelfand EW: The late, but not early, asthmatic response is dependent on IL-5 and correlates with eosinophil infiltration. J Clin Invest 1999, 104(3):301-308.

doi:10.1186/1710-1492-6-S3-P3

Cite this article as: Kam et al.: Functional genomics of the peripheral

blood response to allergen inhalation challenge. Allergy, Asthma \&

Clinical Immunology 2010 6(Suppl 3):P3.

\section{Submit your next manuscript to BioMed Central} and take full advantage of:

- Convenient online submission

- Thorough peer review

- No space constraints or color figure charges

- Immediate publication on acceptance

- Inclusion in PubMed, CAS, Scopus and Google Scholar

- Research which is freely available for redistribution

Submit your manuscript at www.biomedcentral.com/submit 